\title{
Recent Herbal Proprietary Preparations for Liver Diseases: A Comparative Study
}

\author{
Manish S. Yadav ${ }^{1}$, Praveen Buram² \\ ${ }^{1}$ HOD \& Associate Professor, Dept. of Rog Nidan \& Vikriti Vigyan, Nallasopara Ayu. Medical College, \\ Palghar 461301 Maharashtra. \\ ${ }^{2}$ Assistant Professor, Dept. of Kaychikitsa, Bhagwant Ayurvedic College, Bhagwantpuram, 251315(U.P.)
}

Corresponding Author: Manish S. Yadav

\section{ABSTRACT}

Liver is considered to be one of the most vital organs that functions as a centre of metabolism and excretion of waste metabolites. A number of risk factors predispose an individual to hepatic injury and thus liver diseases. Total death worldwide due to liver diseases raised by 50 million per year over two decades, according first ever WHO Study of Liver Disease Mortality. In recent years Indian Traditional Medicines like Ayurveda, Siddha and Unani have gained importance and popularity because of their safety and efficacy in liver diseases. Several Ayurvedic proprietary liver preparations are being extensively used in Ayurveda for the management of liver diseases. About 600 commercial herbal formulations with claimed hepato protective activity are being sold all over the world. In India more than 93 medicinal plants are used in different combinations in the preparation of 40 patented herbal formulations in the form of liquid and tablet. But very little is known when and how these formulations are to be used in present practice.

Out of this easily available most commonly used liver preparations Adliv, Amlicure DS, Arkaliv, Ayuliv, Hepjaun, Kamilari, Kamilari plus, Liv Aid, Livercure, Livergen, Liv 52, Livobell, Livokin, Livomyn, Livpar, Nirocil, Stimuliv, Strongliv, Terfoliv and Vasuliv are taken for the study. These preparations are classified on various basis like available market form, HerboHerbomineral preparations etc. Kutaki is most commonly used single drug in maximum number of preparations followed by Bhringraj, Bhui Aamalaki, and Kalmegh. Individual drugs of the preparations are studied according to Rasa, Virya and Vipaka. Uses of individual
\end{abstract}

drugs as well as of liver preparations are also studied in relations with liver diseases. Present study will definitely give a clue for standard herbal formulations based on physiopathology of liver disease which is a need of a day

Key Words- Liver, Hepato protective, Herbal, Formulations

\section{INTRODUCTION}

The liver is the largest glandular organ in the body, and has more functions than any other human organ. The liver has a pivotal role in human metabolism. It produces and secretes bile (to be stored in the gall bladder until needed) that is used to break down and digest fatty acids. It produces prothrombin and fibrinogen, both blood clotting factors, and heparin, a mucopolysaccharide sulphuric acid ester that helps keep blood from clotting within the circulatory system. The liver converts sugar into glycogen, which it stores until the muscles need energy and it is secreted into the blood stream as glucose. The liver synthesizes proteins and cholesterol and converts carbohydrates and proteins into fats, which are stored for later use. It produces blood protein and hundreds of enzymes needed for digestion and other body functions. The liver also produces urea while breaking down proteins, which it synthesizes from carbon dioxide and ammonia. The liver is responsible for detoxifying the body of poisonous substances by transforming and removing 
toxins and wastes. These toxins and wastes are converted into less harmful substances by the liver and then eliminated from the body.

A liver disease is a term that affects the structure and functions of the liver. A number of risk factors predispose an individual to hepatic injury and thus liver diseases. Total death worldwide due to liver diseases raised by 50 million per year over two decades, according first ever WHO Study of Liver Disease Mortality.

In recent years Indian Traditional Medicines like Ayurveda, Siddha and Unani have gained importance and popularity because of their safety and efficacy in liver diseases. Several Ayurvedic proprietary liver preparations are being extensively used in Ayurveda for the management of liver diseases. About 600 commercial herbal formulations with claimed hepatoprotective activity are being sold all over the world. In
India more than 93 medicinal plants are used in different combinations in the preparation of 40 patented herbal formulations in the form of liquid and tablet. But very little is known when and how these formulations are to be used in present practice. Out of theses easily available most commonly used liver preparations 20 hepato protective formulations are taken for the study.

In this article data was collected and valuable information gathered about the herbal formulations most in demand in Nanded region. These formulations were studied for their active constituents, which were hepatoprotective in nature.

\section{METHODS}

A total 20, easily available and most common Ayurvedic herbal proprietary preparations for liver diseases from Nanded region were taken for the study.

\section{List of formulations:-}

\begin{tabular}{|c|c|c|}
\hline $\begin{array}{l}\text { Serial } \\
\text { no. }\end{array}$ & Formulation & Compositions \\
\hline 1 & F1 & kalmegh, bhrigraj, aamalki, Kutaki \\
\hline 2 & F2 & $\begin{array}{l}\text { bhringraj, bhumyamalki, kalmegh, mandurbhasma, kasani, haritaki, punarnava, guduchi, chitrak, rohitak, arjun, } \\
\text { aamalki, vidanga, tulsiu, kunwarpathi, sharpunkha, pittapapda, shwetaparpati shankhabhasma, kalipeth, kachora, } \\
\text { nishottar, mulishan, yashtimadhu, pravalpishti, kosondi, makoi }\end{array}$ \\
\hline 3 & F3 & Guduchi, raktarohida, daruharidra, aamalki, kutaki, shankhabhasma, kaprdikbasma, dagdiberbhasma \\
\hline 4 & $\mathrm{~F} 4$ & $\begin{array}{l}\text { Bhumyamalki, kasani, bhringaraj, punarnava, shrpunkha, kutaki, vaikranta, mandurbhasma, aarogyavardgini, } \\
\text { yakritplihaharloh }\end{array}$ \\
\hline 5 & F5 & $\begin{array}{l}\text { Bhringaraj, kasvind, pathari, madyantika, daruharidra, nishottar, kalmegha, nim, kutaki, chitraka, } \\
\text { kapardikbhasma, mandurbhasma }\end{array}$ \\
\hline 6 & F6 & Sharpunkha, ella, shunthi, yashtimadhu, maricha \\
\hline 7 & F7 & Vasa, devdaru, parisha, bilwa, ella, danduk, shunthi, jay, pippali, brihati, kandsari \\
\hline 8 & F8 & Kutaki, bhumyamalki, kalmegha \\
\hline 9 & F9 & Shilajeet, chitrak, kutaki, ajmoda, mandurbhasma, bhumyamalki, chvya, abhrakabhasm, trifla \\
\hline 10 & F10 & Kalmegha, kokilaksha, swarnapatri, krishnajeerak, methika \\
\hline 11 & F11 & Hinsra, kasani, mandurbhasma, kakmachi, arjun, kasmarda, zhavuk \\
\hline 12 & F12 & $\begin{array}{l}\text { Haritaki, vatsanabh, bhringraj, sharpunka, chitraka, dantimul, punarnava, nishottar, rohitak, chavya, guduchi, } \\
\text { madayantika, indrayava, kalmegha, vidanga, pippali, tulsi, gulab, shunthi, ajmoda }\end{array}$ \\
\hline 13 & F13 & Kalmegha, daruharidra, musta, bhringaraj, kutaki, chitraka, sharpunkha, arjun, haritaki, methika, kakamachi \\
\hline 14 & F14 & $\begin{array}{l}\text { Kalmegha, kutaki, dhaniya, kunwarpatha, pittapapda, vidanga, sharpunkha, guduchi, daruharidra, shunthi, vasda, } \\
\text { bhringaraj, kasani, rohitaka, punarnava, trifla, krishnajeerak }\end{array}$ \\
\hline 15 & F15 & Bhumyamalki, kutaki, pittapapda, hinsra, bhringaraj, kasani, haritaki, shrpunkha \\
\hline 16 & F16 & Bhumyamalki, eranda, guduchi, zashadbhasma \\
\hline 17 & F17 & Kalmegha, bhringaraj, pittapapda, bhumyamalki \\
\hline 18 & F18 & Kutaki, guduchi, nimbi, vasa, kiratikta, rohitaka, daruharidra, punarnava, shunthi, trifla, eranda \\
\hline 19 & F19 & Kalmegha, tulsi, bhringaraj, bhumyamalki, kutaki, pippali, sharpunkha, haritaki, kakamachi \\
\hline 20 & F20 & Bhringaraj, punarnava, sharpunka, bhumyamalki, kasmarda, kalmegha, katukrohini \\
\hline
\end{tabular}

These preparations are classified on various bases like available dosage form, Herbo-Herbomineral form, major herbal drugs as hepatoprotectives, popular herbal hepatoprotective products, and their uses in relation with liver diseases. The individual drug of liver preparations was also studied according to Rasa, Vipaka and Virya. 


\section{OBSERVATIONS AND RESULTS 1. Comparison of different dosage forms-}

Tablet dosage forms are mostly used as herbal hepatoprotective formulation. It is the dosage form of choice because of better patient acceptability, palatability and availability in local market.

\section{Herbo-Herbomineral form-}

Out of 20 proprietary products 13 preparations had pure herbal content in and rest 7 had mineral content also in it. Most commonly used minerals were mandurbhasma, and kapardika bhasma.

\section{Popular hepatoprotective products-}

About $87.5 \%$ pharmacists of medical stores said that F11 is the best selling hepatoprotective formulation. There are about a total of 61 active ingredients in varying amount, in different herbal formulations. F2 contains the largest quantity of important ingredients.

\section{Major herbal drugs as hepatoprotectives-}

After the survey of data of several products it was concluded that Picrorhiza kurroa (kutaki) is the most important herbal drug that is used in hepatoprotective herbal formulations. Frequency and amount of kutaki is more than the other total 61 active ingredients. Formulation $-\mathrm{F} 15$ contains largest quantity of herbal constituents as compare to others. A total of 61 ingredients were used in different types of hepatoprotective herbal formulations recorded in the present study and based on the frequency, the important ones among them are Picrorhija kurroa (kutaki), Eclipta alba (bhringraj), Phyllanthus amaris (bhumyamlaki), Andrographis paniculata (kalmegh), Cichorium intybus (kasani), Boerrhaavia diffusa (punarnava), Tephrosia purpurea (sharpunkha), Zingiber officinale (shunthi), and. Of the total twenty formulations surveyed, Picrorhiza kurroa(kutaki) was present in 12 hepatoprotective herbal formulations.

\section{Important hepatoprotective plants ${ }^{\mathbf{1}}$ -}

\begin{tabular}{|c|c|c|c|c|c|}
\hline COMMON NAME & BOTANICAL NAME & RASA & VIPAKA & VEERYA & DOSHGHNATA \\
\hline Kasamard & Cassia occidentalis & Tikta madhur & Katu & Ushna & $\mathrm{Kv}$ \\
\hline Kasani & Cichorium intybus & Tikta & Katu & Ushna & $\mathrm{Kp}$ \\
\hline Kakamachi & Solanum nigrum & Tikta & Katu & Anushna & Vpk \\
\hline Katuki & Picrorhiza kurroa & Tikta & Katu & Sheeta & $\mathrm{Kp}$ \\
\hline Amrita & Tinospora cordifolia & Tikta kashaya & Madhur & Ushna & Vpk \\
\hline Arjuna & Termenalia arjuna & Kashaya & Katu & Sheeta & $\mathrm{Kp}$ \\
\hline Aswangdha & Withania somnifera & Tikta katu madhur & Madhur & Ushna & $\mathrm{Kv}$ \\
\hline Amalaki & $\begin{array}{l}\text { Emblica } \\
\text { officinalis }\end{array}$ & Amla pradhan & Madhur & Sheeta & Vpk \\
\hline Ajmoda & Carum roxburghianum & Katu Tikta & Katu & Ushna & $\mathrm{Kv}$ \\
\hline Punarnava & Boerhavia diffusa & $\begin{array}{l}\text { Madhur } \\
\text { tikta } \\
\text { kashaya }\end{array}$ & Madhur & Ushna & Vpk \\
\hline Hanspadi & Adtiantum lunulatum & Kashaya & Madhur & Sheeta & $\mathrm{Kp}$ \\
\hline Haritaki & Terminalia chebula & Kashaya & Madhur & Ushna & Vpk \\
\hline Haridra & Curcuma longa & Tikta katu & Katu & Ushna & $\mathrm{Kv}$ \\
\hline Kalmegh & Andrographis paniculata & Tikta katu & Katu & Ushna & $\mathrm{Kp}$ \\
\hline Kurchi & Halorhenna pubescens & Tikta kashaya & Katu & Sheeta & $\mathrm{Kp}$ \\
\hline Chirayata & Swertia chirayita & Tikta & Katu & Ushna & Vpk \\
\hline Papaya & Carica papaya & Katu Tikta & Katu & Ushna & $\mathrm{Vk}$ \\
\hline Daruharidra & Berberis aristata & Tikta kashaya & Katu & Ushna & $\mathrm{Kp}$ \\
\hline \multirow[t]{2}{*}{ Dhaniya } & Coriandrum & Kashaya & Madhur & Ushna & Vpk \\
\hline & sativum & $\begin{array}{l}\text { tikta } \\
\text { madhur katu }\end{array}$ & & & \\
\hline Mishreya & Foeniculum vulgare & $\begin{array}{l}\text { Madhur } \\
\text { Katu Tikta }\end{array}$ & Madhur & Sheeta & $\mathrm{Vp}$ \\
\hline Taruni & Rosa centifolia & $\begin{array}{l}\text { Tikta kashaya } \\
\text { Madhur }\end{array}$ & Madhur & Sheeta & $\mathrm{Vp}$ \\
\hline Gokharu & Tribulus terrestris & Madhur & Madhur & Sheeta & $\mathrm{Vp}$ \\
\hline Trivritta & Operculina terpethum & Tikta katu & Katu & Ushna & $\mathrm{Kp}$ \\
\hline Parpata & $\begin{array}{l}\text { Fumaria } \\
\text { vaillantii }\end{array}$ & Tikta & Katu & Sheeta & $\mathrm{Kp}$ \\
\hline
\end{tabular}




\begin{tabular}{|c|c|c|c|c|c|}
\hline \multicolumn{6}{|c|}{ Table Continued... } \\
\hline Pudina & Mentha spicata & Katu & Katu & Ushna & $\mathrm{Kv}$ \\
\hline Tambul & Piper betle & Katu Tikta & Katu & Ushna & $\mathrm{Kv}$ \\
\hline Rohitak & Tecoma undulata & Katu Tikta kashaya & Katu & Sheeta & $\mathrm{Kp}$ \\
\hline Peelu & Salvadora persica & Tikta Madhur & Katu & Ushna & $\mathrm{Kv}$ \\
\hline Eranda & Ricinus communis & Madhur Katu kashaya & Madhur & Ushna & $\mathrm{Kv}$ \\
\hline Vibhitaka & Terminalia bellirica & Kashaya & Madhur & Ushna & $\mathrm{Vpk}$ \\
\hline Vidanga & Embelia ribes & Katu kashaya & Katu & Ushna & $\mathrm{Kv}$ \\
\hline Vasaka & Adhatoda vasika & Tikta kashaya & Katu & Sheeta & $\mathrm{Kp}$ \\
\hline Hinsra & Capparis sepiaria & Katu Tikta & Katu & Ushna & $\mathrm{Kv}$ \\
\hline Maricha & Piper nigrum & Katu & Katu & Ushna & $\mathrm{Vk}$ \\
\hline Revandchini & Rheum emodi & Tikta Katu & Katu & Ushna & $\mathrm{Kp}$ \\
\hline Bhringraj & Eclipta alba & Katu Tikta & Katu & Ushna & $\mathrm{Kv}$ \\
\hline Chitrak & Plumbago zeylanica & Katu & Katu & Ushna & $\mathrm{Kv}$ \\
\hline Tulsi & Ocimum sactum & Katu Tikta & Katu & Ushna & $\mathrm{Kv}$ \\
\hline Shunthi & Zingiber officinale & Katu & Madhur & Ushna & $\mathrm{Kv}$ \\
\hline Sharphunkha & Tephrosia purpurea & Tikta kashaya & Katu & Ushna & $\mathrm{Kv}$ \\
\hline Madayantika & Lawsonia inermis & Tikta kashaya & Katu & Sheeta & $\mathrm{Kp}$ \\
\hline $\mathrm{Nimb}$ & Azadirachta indica & Tikta kashaya & Katu & Sheeta & $\mathrm{Kp}$ \\
\hline
\end{tabular}

Hepatoprotective plants of most of the liver preparations were predominantly of Tikta rasa, Katu vipaka and ushna veerya with pitta kapha shaman property.

\section{DISCUSSION \\ IMPORTANT HERBAL HEPATO- PROTECTIVES-}

Andrographis paniculata (Kalmegh) Andrographolide, the active constituent isolated from the plant Andrographis paniculata, showed a significant dose dependent protective activity against paracetamol-induced toxicity on ex vivo preparation of isolated rat hepatocytes. It significantly increased the percent viability of the hepatocytes as tested by tryptan blue exclusion and oxygen uptake tests. It completely antagonized the toxic effects of paracetamol on certain enzymes (GOT, GPT and alkaline phosphates) in serum as well as in isolated hepatic cells. Andrographolide was found to be more potent than silymarin, a standard hepatoprotective agent. ${ }^{2}$

Boerhavia diffusa (Punarnava) An alcoholic extract of whole plant Boerhavia diffusa given orally exhibited hepatoprotective activity against experimentally induced carbon tetrachloride hepatotoxicity in rats and mice. The extract also produced an increase in normal bile flow in rats suggesting a strong choleretic activity. The extract does not show any signs of toxicity up to an oral dose of $2 \mathrm{~g} / \mathrm{kg}$ in mice. ${ }^{3}$
Eclipta alba (Bhringraj) The hepatoprotective effect of the ethanol/water (1:1) extract of Eclipta alba was studied at subcellular levels in rats against (CCl4) induced hepatotoxicity. The loss of hepatic lysomal acid phosphatase and alkaline phosphatase by (CCl4) was significantly restored by Ea. Hepatoprotective activity of $\mathrm{Ea}$ is by regulating the levels of hepatic microsomal drug metabolizing enzymes. ${ }^{4}$

Picrorhiza kurroa (Katuki) Picrorrhiza Kurroa is one of the herbs recommend to support the liver not only in everyday situations, but in cases where severe viral infections exists: a study by Vaidya et al found protection against viral hepatitis, and other studies have demonstrated its helpfulness in protecting against alcohol. ${ }^{5}$

Cichorium intybus (Kasani) It is a popular ayurvedic remedy for the treatment of liver diseases. It is commonly known as kasani and it is a part of polyherbal formulations used in the treatment of liver diseases. Optimum properties were seen with a dose of $75 \mathrm{mg} / \mathrm{kg}$ given $30 \mathrm{~min}$ after $\mathrm{CCl} 4$ intoxication. In preclinical studies its alcoholic extract was found to be effective against chlorpromazine induced intoxication. ${ }^{6}$

Tephrosia purpurea (Sharpunkha) Alkaline preparation of Tephrosia purpurea is used in treatment of liver and spleen diseases. It is protective against $\mathrm{CCl} 4$ and D-galactosamine poisoning. ${ }^{7}$

Zingiber officinale (Shunthi) It is used as antiemetic. Its adsorbent aromatic and 
carminative properties on entero-intestinal tract causes adsorption of toxins and acids enhanced gastric motility. ${ }^{7}$

Phylanthus amaris (Bhumyamlaki) Main application of Bhumyamlaki is in viral infection of the liver, specifically Hepatitis B. Thyagaran et al. reported that of $22-37$ cases of hepatitis B were cured after using the herb for a month. ${ }^{8}$

\section{FUTURE SCOPE}

Herbal medicines are now in great demand in the developing world for primary health care not because they are inexpensive but also for better cultural acceptability, better compatibility, with the human body and minimal side effects. Global acceptance of Ayurveda is gearing up there has been a steep rise in the demand for medicinal plants from India. Presently the United States is the largest market for Indian botanical products accounting for about $50 \%$ of the total exports. However recent findings indicate that all herbal medicines may not be safe as severe consequences are reported for some herbal drugs. ${ }^{9}$ Globally there have been concerted efforts to monitor quality and regulate the growing business of herbal drugs and traditional medicine. Health authorities and governments of various nations like United States congress, US Food and Drug Administration (FDA) and World Health Organization (WHO) are keen regarding traditional medicine and have been active in creating strategies, guidelines and standards of botanical medicines. WHO, USFDA, European Scientific Cooperative on Phytomedicine (ESCOP), have published standard sets of guidelines to address the concerns. ${ }^{10}$ The publication of Indian Herbal Pharmacopoeia and Ayurvedic Pharmacopoeia are a positive step towards the standardization of herbal drugs. Regulatory norms have to be stringent for nutraceutical preparations and herbal drugs so that the variation between similar contents in different formulations may cease and a scientific approach with definite constituents may be possible for herbals as well.

\section{CONCLUSION}

After the data collection and survey of hepatoprotective formulations, it was concluded that various herbal constituents are used as hepatic drugs, Kutaki being the most popular hepatoprotective agent.

Frequently used constituents for herbal hepatoprotective formulations are Picrorhija kurroa Andrograpis paniculata, Boerrhaavia diffusa, Cichorium intybus, Tephrosia purpurea, Phylanthus amaris, Zingiber officinale and Eclipta alba.

Diseases for which these formulations are mainly used are hepatotoxicosis, liver damage, jaundice, hepatitis and in treatment of loss of appetite.

It was concluded that tablet dosage forms are most commonly used.

From the study it was concluded that herbal medicine is still the mainstay of about $7580 \%$ for primary health care. The use of herbal remedies throughout the world exceeds that of the conventional drugs by two to three times. The advantages of herbal hepatoprotectives are that they are relatively easier to store and have fewer side effects. These are the reasons that herbal hepatoprrotectives are mostly preferred by medical practitioners, as well as over- thecounter. $^{10}$

\section{Acknowledgement: None}

\section{Conflict of Interest: None}

\section{Source of Funding: None}

\section{REFERENCES}

1. Aacharya Priyavrata Sharma, Dravyaguna Vigyana, edition-2006, Chaukhamba Bharati Academy.

2. Visen PK, Shukla B, Patnaik GK, Dhawan BN. Andrographoiliode protects rat hepatocytes against paracetamol - induced damage. J Ethnopharmacol 1993; 40:2, 131136.

3. Ansari RA, Tripathi SC, Patnaik GK, Dhawan BN. Antihepatotoxic properties of picroliv: an active fraction from rhizomes of Picrorhiza kurrooa. J Ethnopharmacol. 
1991 Aug;34(1):61-8. doi: 10.1016/03788741(91)90189-k.

4. Chandan BK, Sharma AK, Anand KK. Boerhavia diffusa: a study of its hepatoprotective activity. J Ethnopharmacol 1991;31:3,299-307.

5. Vaidya. Better Nutrition. 1999; 29.

6. Sherlac S. Diseases of Liver and Biliary System. 8th. ed. Oxford Blackwell Scientific 1989.

7. Kokate CK, Purohit AP, Gokhale SB, Pharmacognosy, 12th edition

8. Rajamani K. Production technology for major medicinal plants. IMAP Today, Indian Medicinal and Aromatic Plants Today. 2004.
9. Pal SK, Shukla Y. Herbal medicine: Current status and future. Asian Pacific Journal of Cancer Prevention. 2003; 4.

10. Bhushan Patwardhan, Dnyaneshwar Warude, P. Pushpangadan, Narendra Bhatt. Ayurveda and traditional Chinese medicine: A comparative overview. eCAM 2005; 2:4, 465-473.

How to cite this article: Yadav MS, Buram P. Recent herbal proprietary preparations for liver diseases: a comparative study. International Journal of Research and Review. 2021; 8(10): 202-207. DOI: https://doi.org/10.52403/ijrr. 20211025 